\title{
Understanding sustainable seafood consumption behavior: an examination of the Ocean Wise (OW) initiative in British Columbia
}

\author{
$\underline{\text { Katherine M. Dolmage }}^{1}$, Victoria Macfarlane ${ }^{2,3}$ and Jamie Alley $^{1,4}$
}

\begin{abstract}
Sustainable seafood labeling programs have been developed as one of several efforts to address the current dire trends in fish stocks. The Ocean Wise (OW) program, started at the Vancouver Aquarium (Canada), works with restaurateurs and suppliers to simplify sustainable purchasing decisions. By aiding restaurateurs with responsible purchasing, OW hopes to shift demand to sustainable seafood products. OW has grown in numbers and spread across Canada quickly; we examine the factors associated with individual and organizational decisions to participate in the program, including personal, business, and program-related factors. These factors were examined in relation to OW membership by Vancouver restaurateurs. Results show that restaurateurs with greater knowledge of seafood issues and restaurants with greater commitment to a range of green initiatives are more likely to participate in the OW program. By focusing efforts on education and incorporating a range of green values into marketing, OW can maximize their limited resources to grow membership.
\end{abstract}

Key Words: BC; British Columbia; consumer behavior; Ocean Wise; OW; restaurant; seafood; sustainability

\section{INTRODUCTION}

Increased demand on global fish populations has depleted stocks around the world (FAO 2014). Unsustainable fishing practices, habitat destruction, and illegal, unreported, and unregulated (IUU) fisheries undermine sustainability initiatives (Agnew et al. 2009, Salomon and Holm-Müller 2013, Environmental Justice Foundation [date unknown]). The tenfold growth in aquaculture production since 1970 (FAO 2011) has offset the leveling of wild catches, but concern around associated effects have been raised (Bostock et al. 2010). Many ideas have been presented to reverse the trend of depleting fisheries, including sustainable seafood certification or recommendation programs (Jacquet et al. 2010). We consider the consumer labeling program Ocean Wise (OW) as a strategy to support fishers and farmers who operate sustainably.

Many researchers have studied drivers of environmentally responsible behavior (ERB; e.g., De Young 1993, McKenzieMohr 2000, Osbaldiston and Sheldon 2003, Clayton and Brook 2005), and green initiatives in restaurants specifically ( $\mathrm{Hu}$ et al. 2010). Growth in the certification/labeling industry and sustainable seafood purchasing is documented in the literature (Ponte 2012, Konefal 2013), but less well studied are the impacts on the environment (Roheim 2003). Although quantification of environmental impact is extremely difficult to determine, Sklandany and Vandergeest (2004) suggest that seafood labeling campaigns should be promoted, even if there is only a small possibility of conservation effect. Bowen and Aragon-Correa (2014) are optimistic about the possibility of change associated with eco-campaigns.

\section{Theoretical perspectives}

For the purpose of this study, sustainable seafood purchasing is considered an example of ERB. Environmentally responsible behavior is described as "a move away from inherently wasteful and damaging behaviours and a move towards conservationoriented" behaviors (Osbaldiston and Shelton 2003:349). The goal of sustainable seafood programs is to "harness market forces to encourage behavioural changes in fisheries" (Gulbrandsen 2009:655). Research suggests three sets of factors are related to a restaurateur's adoption of environmental programs in general, and sustainable seafood programs in particular: personal, business, and program factors.

Personal factors may include personal interest and knowledge of the restaurateur (Hungerford and Volk 1990). We consider the New Environmental Paradigm (NEP) as a measure of environmental value (Dunlap et al. 2000). Although some researchers have found significant correlation between NEP and ERB (Chung and Poon 2000), others have found the NEP too general to predict specific behaviors (Schultz 2000). Culture and demographics also play a role in ERB (Lee et al. 2005); higher education (Hungerford and Volk 1990), income (Verbeke et al. 2007), age (youth; Olli et al. 2001), and gender (female; McCright 2010, Mobley et al. 2010) all are positively correlated with ERB.

Business models are, most often, built on environmental performance. Although traditional models see environmental sustainability as a cost (Gupta and Benson 2011), new strategies can add value (Johnson 1998, Handfield et al. 2005, StubblefieldLoucks et al. 2010, Bush et al. 2015). In fact, Gupta and Benson (2011:123) found that "well executed sustainability programs can lead to dramatic improvements in a company's operational effectiveness." In addition to commercial gains, eco-labels can help to achieve indirect benefits including brand reputation, transparency, and accountability (Dauvergne and Lister 2012). Schubert et al. (2010) found that restaurateurs can create stronger relationships with customers by engaging in green practices, and, although cost and lack of awareness are major barriers (Freeman 2011), an increasing number of people are willing to pay a premium for environmentally friendly products (Laroche et al. 2001).

Labeling programs can create a sense of consumer empowerment (Peattie 2010). Fisheries science is, in its nature, uncertain. To

${ }^{1}$ Coastal and Marine Management, University Centre of the Westfjords, ${ }^{2}$ Global Studies, Vancouver Island University (VIU), ${ }^{3}$ Director of Belize Institute for Local Development (BILD), ${ }^{4}$ Department of Geography, University of Victoria 
achieve results, consumers must trust the credibility of the message they are given (Boström 2006). This can be done through provision of clear, unambiguous information about seafood products (Parkes et al. 2010). Inconsistency, including differing rankings for similar species, can create confusion and diminish program success (McKenzie-Mohr 1994, Iles 2007, Gulbrandsen 2009, Shelton 2009, Moye 2010, Parkes et al. 2010).

Environmental groups are seen as "unbiased protector[s] of the environment" and assure consumers that they can have confidence in environmental claims (Mendleson and Polonsky 1995:16). Groups such as WWF or Greenpeace are seen as less biased than governments, and therefore better able to run these programs (Moye 2010, Roberts 2010). In addition, aquariums and zoos have the ability to provide data and understanding to make conservation programs successful (Smith et al. 2007).

For seafood labeling programs to be most effective, the factors driving restaurateur behavior need to be studied and understood. In the present study we aim to address the question of what has made OW successful thus far, and what lessons can be learned to ensure the program continues to expand to ultimately make a difference in the global seafood crisis. The study examines the factors that motivate restaurateurs to, or deter them from, making sustainable seafood choices. Behavioral characteristics that distinguish member restaurateurs from nonmember restaurateurs are evaluated. The barriers and facilitators to sourcing sustainable seafood were considered to determine how OW can help to reduce barriers and strengthen facilitators. Finally, the effectiveness of the program, in terms of restaurant membership and proportion of recommended seafood on restaurant menus, are assessed.

\section{METHODS}

\section{Case study}

Ocean Wise is a consumer-based eco-labeling program that was launched by the Vancouver Aquarium in 2005. The goal of the program is to "educate and empower consumers about the issues surrounding sustainable seafood" (Ocean Wise [date unknown]). Through partnerships with Seafood Watch and SeaChoice, OW receives scientific assessments of global fisheries and aquaculture operations. These assessments score management effectiveness, data availability, stock status, and other factors to create a numerical sustainability score (Seafood Watch 2015). If the assessment results in a sufficiently high score, the seafood receives an OW recommendation. Detailed information on scoring and full recommendation reports are available at http://www. oceanwise.ca. Unlike the stoplight systems used by the Seafood Watch and SeaChoice programs, OW simply scores products a yes or no.

Ocean Wise is a recommendation program, rather than a seafood certification (such as the Marine or Aquaculture Stewardship Council-MSC/ASC); third party audits are not conducted. Although no chain of custody audit takes place, the program can help to reduce seafood fraud (Jacquet and Pauly 2008a, Hanner et al. 2011, Golden and Warner 2014) by demanding that restaurateurs ask questions and obtain greater information from their seafood suppliers.

Ocean Wise reports are primarily generated for products important to the North American marketplace without fee, rather than being producer initiated and funded. Recommendations are generally conducted by area and production method (e.g., British Columbia groundfish). Though this process may reduce the political and economic conflicts and competition between producers that certification schemes create (e.g., Foley 2012), it focuses only on larger producers or producers with wider markets. Lack of opportunity for small-scale fisheries can be an issue with programs such as OW (Jacquet and Pauly 2008b).

Ocean Wise, like other seafood labeling programs, highlight sustainable choices in hopes that, when given the option, consumers will preferentially purchase more environmentally friendly seafood. Member businesses may place the OW logo next to recommended seafood to make sustainable purchasing decisions easy. The OW program works with restaurants, suppliers, and markets. Sustainable products may demand higher prices; research shows consumers are willing to pay a $5 \%-10 \%$ premium for sustainable seafood products (Seafood Choices Alliance 2007), and Kemmerly and Macfarlane (2009) found that $92 \%$ of aquarium visitors surveyed would preferentially choose responsible seafood over others. Labeling programs help consumers make informed decisions about their consumption.

To become an OW member, restaurateurs must submit their current seafood procurement list to OW staff for review. Items that are OW recommended will be identified, while alternatives to other items are suggested. Initially, restaurateurs must only source one OW menu item, but they must commit to replacing unsustainable items in the future. Membership of Vancouver's largest seafood suppliers such as Albion Seafoods makes identifying recommended options simple for restaurateurs. Benefits to membership include listing on the OW website, invitations to feature events such as the annual "Chowder Chowdown," and access to OW expertise and advice. Program growth in British Columbia has been steady; at its launch in 2005 , the program had 22 members in the Vancouver area. Current membership is over 450 members with 3100 locations from coast to coast. Initially a free service, OW now charges an annual fee of $\$ 250$ per member to offset operating costs.

\section{Research design}

Data were gathered through interviews with three groups of restaurateurs: current OW members, previous OW members, and restaurants with no affiliation to OW. Selection of interviewees was random. Ocean Wise restaurants invited to participate in interviews were selected from a list of all OW restaurants in Vancouver. Eighty restaurateurs were contacted, two restaurants had closed, two had left the program, and 34 agreed to interviews for a response rate of $45 \%$. Non-OW restaurants were selected according to several predetermined criteria. A list of mid- to highend seafood serving nonmember restaurants in Vancouver was created, and 84 were contacted: 12 were excluded because of language barriers; 32 of the remaining 72 agreed to participate, for a response rate of $44 \%$. Only nine restaurants in Vancouver were identified as having left the OW program while remaining in operation. Of these, four agreed to participate (44\%). Because of the small sample size of the third group, it was assumed that nonmembers and former-members would share some characteristics, and groups were combined for analysis.

Interviews were conducted with the decision maker at each restaurant, either the head chef or owner. Ocean Wise program 
data, supplier data from Albion Fisheries (the largest seafood supplier in Western Canada), and restaurant menu information was analyzed. Interviews took approximately 30 minutes and consisted of semistructured, open and closed-ended questions (Appendix 1). Restaurateurs were asked both subjective (e.g., How would you rate your knowledge of seafood sustainability?) and objective (e.g., Are BC trap caught spot prawns sustainable?) questions about seafood (Appendix 1). Likert scales were used for their simple and efficient measurements (Roberts et al. 1997), to score (from 1 - not at all important to 5 - extremely important) a number of factors associated with purchasing seafood, including sustainability, price, and quality.

The content of interviews differed between the three groups of restaurateurs. Interview questions for all restaurateurs included general knowledge of fisheries, issues surrounding sustainable fisheries, knowledge of the OW program or other sustainable seafood programs, and knowledge of green restaurant initiatives in general. A modified NEP scale survey (Cordano et al. 2003), which quantifies each restaurateur's level of environmental concern, was given to each interviewee, as well as survey questions to determine the interviewee's knowledge of sustainable seafood issues.

A set of questions specific to each of the three restaurateur categories was also administered. For current OW members, these questions focused on their program experience and perceived value of membership. Non-OW questions focused on restaurateurs' understanding of the program, and factors that would encourage or discourage future membership. Ex-OW restaurateur surveys considered reasons for leaving. These questions considered personal, business, and program factors. Each of the variables is defined below, while the full survey is included in Appendix 1:

- Knowledge of sustainable seafood issues: a set of questions designed to assess knowledge of sustainable seafood issues. These questions addressed knowledge of sustainable practices and species.

- Environmental attitudes: the modified NEP scale was used to determine environmental attitudes.

- Barriers/facilitators to purchasing sustainable seafood: perceived barriers to sourcing sustainable seafood, perceived price premium of sustainable products.

- Commitment to serving sustainable seafood: assessed using OW program information and restaurant menus. Length of membership, percentage of sustainable items, and other promotion of sustainable seafood.

- Green image: green initiatives in addition to OW, including recycling, support of local food, or membership in an organization such as the Green Restaurant Association.

- Services/benefits of Ocean Wise: questions on benefits and most useful services member restaurants receive, as well as services they would like to receive.

- Emphasis on green values vs. cost: ranking of importance of factors when purchasing seafood.

Quantitative data from interviews and surveys were analyzed using SPSS software. Descriptive statistics were used to create a broad understanding of the samples and data gathered. T-Tests and chi-square analyses were used to identify significant differences between groups of restaurants studied. Correlational analyses were conducted to evaluate the strength of the relationships between variables. Multiple regression analysis was conducted to determine the relationship between multiple variables and the relative contribution of specific combinations of variables.

A stepwise regression analysis was conducted to assess the relationship between several personal factors, including environmental knowledge and the importance restaurateurs placed on environmental sustainability when purchasing seafood for their restaurants. Content-analysis of qualitative responses to specific open-ended questions was conducted, identifying common themes and frequency of mention. Representative quotes were extracted where appropriate.

\section{RESULTS}

\section{Personal factors}

Relationship between environmental knowledgelattitudes and $\mathrm{OW}$ membership

Restaurateur scores on a modified NEP scale (Dunlap et al. 2000) and knowledge of sustainable seafood issues (sustainability of products, fishing methods, etc.) were evaluated using a scale constructed specifically for this study and based on issues relevant to the region (see Appendix 1). NEP scores were not significantly different $(p=0.997)$. Significant differences (Fig. 1) were found in the knowledge, both self-identified and scored, of the two groups, with OW members scoring higher on knowledge of fishing practices $(\mathrm{p}=0.004 ; \mathrm{p}=0.002)$ and sustainable products $(\mathrm{p}=$ $0.004 ; \mathrm{p}=0.002)$.

Fig. 1. Relationship between environmental knowledge attitude and Ocean Wise membership.

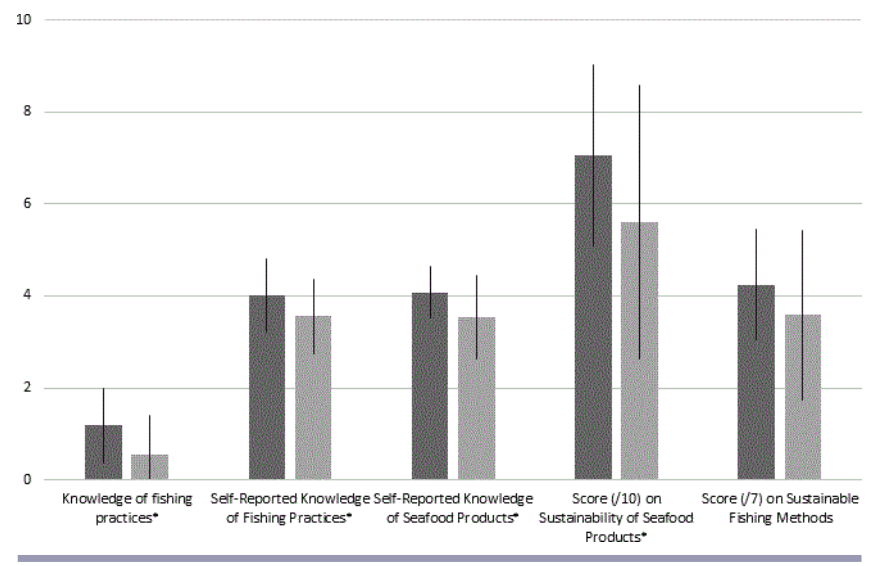

Of the OW restaurateurs surveyed, only 3 of $34(8.8 \%)$ respondents completely lacked knowledge of what fishing practices were being used for the seafood products they were selling. At non/ex-OW restaurants, on the other hand, 18 of 32 $(56 \%)$ had no knowledge of these practices. Ocean Wise restaurateurs gave descriptions of the fishing practices, such as: "hook and line, troll, trap for prawns," or described having had conversations with their suppliers regarding fishing method 
before ordering products. Many OW restaurateurs remarked that a knowledgeable supplier, who readily supplies information regarding sustainability, was very important to their seafood purchasing decisions. Although some non-OW restaurateurs appeared to be aware of and concerned about the notion of sustainable fishing practices, they did not have knowledge specific to the fish that they purchased or the fishing practices used. One restaurateur described his understanding as "probably a big ship with a big net in the back or a big line where the halibut get caught. I would probably not agree with it."

\section{Commitment to the Ocean Wise program}

Most OW restaurateurs had noticed changes in fish supply in recent years. Notable changes identified included a decrease in supply and availability $(58.8 \%)$, increase in price $(26.5 \%)$, and decrease in size of fish being sourced $(11.8 \%)$. One restaurateur stated, "Any of the swordfish and bill family fish, the size has been reduced dramatically, the same with tuna. Halibut has never been the same, you used to get 40 to 60 pounds, now you get 10 to 20 pounds ... ground fish has become more scarce ... depletion of the skate, it's not seen anymore. Dungeness crab and lobster has become abundant and cheap."

Of 35 OW members, 29 (83\%) felt that their membership in the program was having at least a small positive impact; four members felt their impact was either too small to count or nil. Many OW restaurateurs felt that, regardless of how small their individual impact, the group effect would have an overall positive impact on fish stocks. One member stated "you always think you don't really count, I'm only one vote out of a million, but at the end of the day it does. If we all start thinking that then no one bothers to buy Ocean Wise ... then it can swing in a big amount." The strongest model R-square (0.29) was obtained with the entry of three variables: knowledge of the methods used for seafood products being sold, whether or not the restaurateurs believed that sustainable seafood must be wild caught, and rank of the importance of sustainability when ordering seafood.

\section{Business factors}

The majority of OW restaurateurs surveyed identified a shared vision or set of beliefs that was common to those of OW as their main reason for joining the program, while others joined because of customer demand. Restaurateurs were expecting more restaurants to follow suit: "When it started, top chefs were on board. Moving into the future, people are ethically choosing where they go. If you're not Ocean Wise, people won't go.”

Importance of sustainability when purchasing seafood

Restaurateurs scored the importance of a number of factors when purchasing seafood, from 1 (not important) to 5 (extremely important), and also ranked the same factors from most important to least important. Results, presented in Figures 2 and 3 , show OW restaurateurs scored and ranked environmental sustainability significantly higher than non-OW restaurateurs. Some confusion over the term "freshness" was expressed by both groups of restaurateurs, with some considering "frozen at sea" seafood as not fresh and therefore ranking freshness lower than other factors.

\section{Commitment to other green activities}

Vancouver's image as an environmentally friendly city is well established, and it aims to be the "greenest city in the world by
2020" (City of Vancouver 2015). There are many activities that may be performed by a business owner that reflect environmental responsibility, including recycling, composting, purchasing local products with inherently reduced carbon footprints, or reducing energy consumption. OW and non/ex-OW restaurants were compared based on the number and extent of "green" in which they were engaged. Of all restaurateurs interviewed, $83 \%$ participated in some sort of green activity. At a minimum, recycling programs were in place at 58 of the 70 restaurants interviewed. Specific activities are presented in Table 1.

Fig. 2. Ocean Wise versus non-Ocean Wise values of the importance of each category when purchasing seafood.

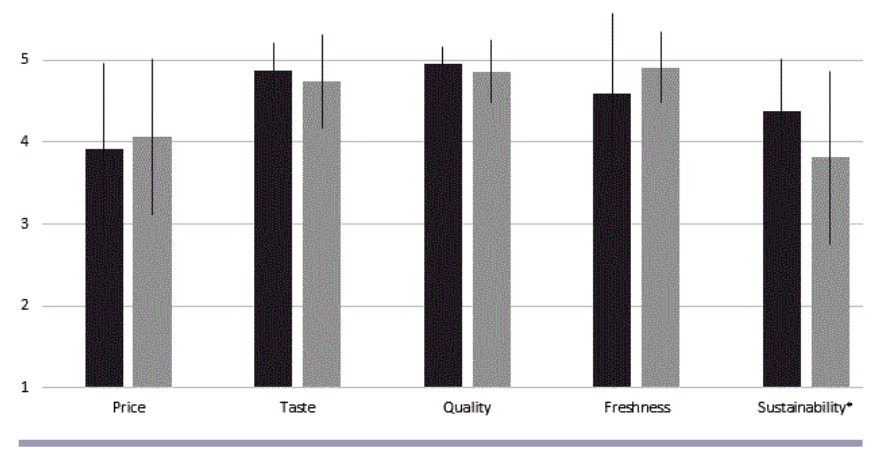

Fig. 3. Ocean Wise versus non-Ocean Wise rank of factors when purchasing seafood.

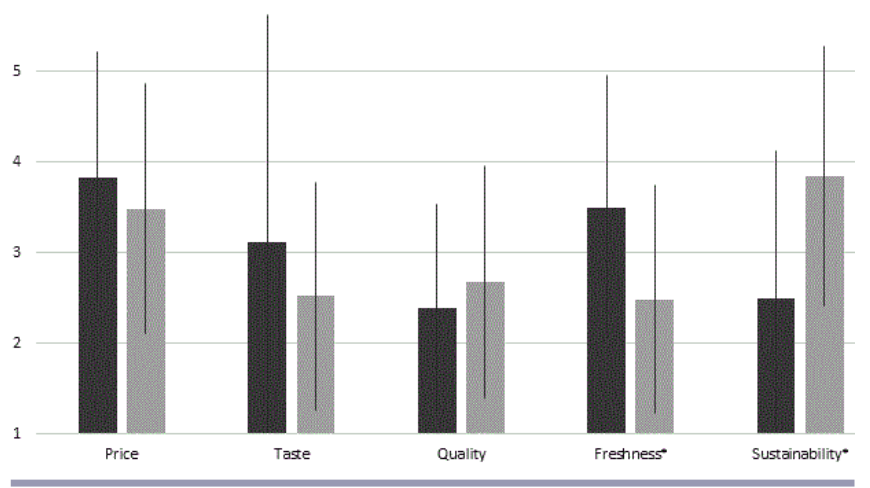

Table 1. Green activities taking place at restaurants.

\begin{tabular}{lcccc}
\hline \hline Activity & $\begin{array}{c}\text { Ocean Wise } \\
(\mathrm{OW}) \\
\mathrm{N}=34\end{array}$ & Percent OW & $\begin{array}{c}\text { Non/Ex-OW } \\
\mathrm{N}=31\end{array}$ & $\begin{array}{c}\text { Percent Non/ } \\
\text { Ex-OW }\end{array}$ \\
\hline $\begin{array}{l}\text { Recycling/ } \\
\text { Composting }\end{array}$ & 29 & 85.30 & 24 & 77.40 \\
$\begin{array}{l}\text { Local/ } \\
\text { Organic }\end{array}$ & 12 & 35.30 & 7 & 22.60 \\
$\begin{array}{l}\text { Products } \\
\text { Energy } \\
\text { Efficiency } \\
\begin{array}{l}\text { Other Green } \\
\text { Activities }\end{array}\end{array}$ & 11 & 32.40 & 3 & 9.70 \\
None & 3 & 23.50 & 5 & 16.10 \\
\hline & 8.80 & 6 & 19.40 \\
\hline
\end{tabular}


There was no significant difference between restaurant membership in OW and the presence at least one green activity. Significant difference $(p=0.010)$ was found in the number of green activities taking place at $\mathrm{OW}$ vs. non-OW restaurants, when scored using a scale of 0 : no green activities; 1 : only recycling; 2 : recycling and some other green activity; 3: fully committed to green activities, i.e., recycling, composting, sourcing local products, green cleaning products, energy reduction, etc. Seventysix percent of OW restaurants scored a 2 or 3 on the scale, while only $48.5 \%$ of non-OW restaurants met this criterion.

Seventy-nine percent (27 of 34) of OW restaurateurs felt that program membership was extremely important for the image they were attempting to portray for the restaurant, that responsible, sustainable sourcing decisions were being made. Restaurateurs felt strongly that membership attracted customers to their restaurants. Additionally, they valued the publicity that they received from $\mathrm{OW}$, and many expressed interest in receiving even more assistance in this regard.

\section{Perceived costs and financial impacts}

Of the 34 OW restaurateurs interviewed in this study, $15(44 \%)$ felt that being a member of the program had a positive financial impact on their restaurant. Despite the $\$ 250$ membership fee, and the perception by the majority $(61.7 \%)$ of restaurateurs that sustainable choices are more expensive (Fig. 4), no restaurateur felt that membership was a financial burden. Costs may be offset by the additional business that membership brings. The majority of non-OW restaurateurs $(53.3 \%)$ did not feel that the $\$ 250$ fee would prevent them from joining the program.

Fig. 4. Price premium between Ocean Wise and non-Ocean Wise seafood items.

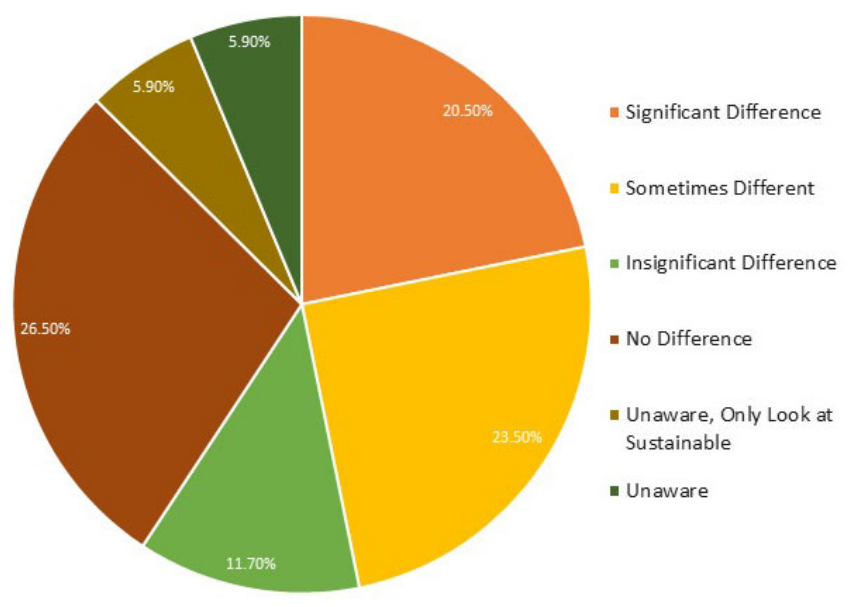

Menu analysis of OW restaurants shows that the average price of sustainable items is greater than that of nonsustainable items. The average price of sustainable seafood items is $\$ 17.75(\mathrm{SD}=6.53)$ whereas the average price of nonsustainable items is $\$ 14.87$ (SD $=6.59$ ). These data suggests that any increased cost purchasing sustainable items can be offset by an increased price of less than $\$ 3.00$ or about $19 \%$.

\section{Product availability}

Barriers to sourcing sustainable products were assessed in interviews. The majority of restaurateurs had difficulty finding specific sustainable products. Prawns were identified as the most difficult sustainable product to source: "very difficult to find a sustainable prawn," "local prawn season is so short and the price is quite high," "mainly issues with prawns; I haven't been using sustainable prawns for the last one to two months because the price and quality are not good."

Some non-OW restaurateurs purchased seafood from suppliers who include sustainability information with orders, and therefore they knew they were sourcing sustainable products. Barriers nonmembers identified as present to sourcing sustainable product are included in Figure 5.

Fig. 5. Barriers to sourcing sustainable products identified by non-Ocean Wise members.

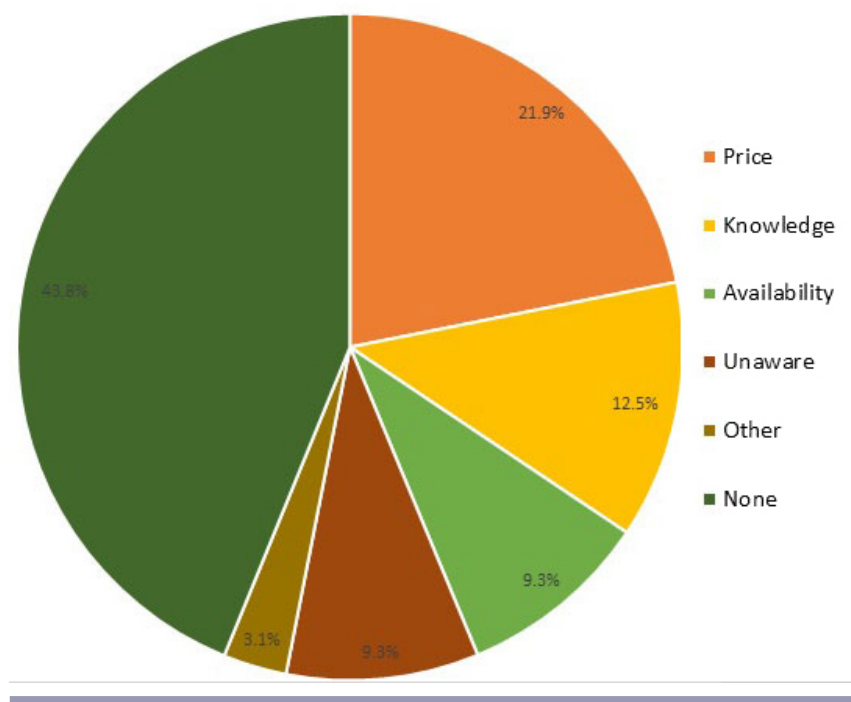

\section{Program factors}

Growth in the OW program has been steady. Results of this study show a mean level of satisfaction of 4.1 with the OW program, on a scale of 1 (not at all satisfied) to 5 (extremely satisfied). No restaurateur a value lower than 3 . The perceived credibility of the OW program was found to be very high. Over $90 \%$ (31 of 34) of OW restaurateurs believed the program provided credible information. Ocean Wise restaurateurs who did not agree that the program was credible stated concerns that information was too general or insufficient, rather than lacking credibility. Of nonOW restaurateurs, $69.4 \%$ (25 of 36) felt the program was reliable; however $25 \%$ ( 9 of 36 ) were unfamiliar and unable to comment. During this research, a number of nonmember restaurants were found to be using the OW logo.

More than half $(58.8 \%)$ of OW restaurateurs confirmed that they contacted OW staff for help in sourcing more sustainable seafood. Over $30 \%$ of members ( 11 of 34 ) felt that providing information on sustainable products and suppliers was the most important service that OW provided. One restaurateur commented "without 
that list you wouldn't have a clue of what's going on, without that list everybody would be ordering whatever they feel like."

\section{DISCUSSION}

The Ocean Wise program is committed to promoting conservation through education, which is vital for sound decision making with respect to environmental issues (Hungerford and Volk 1990). Although the NEP scale provides a good measure of environmental concern (Dunlap at al. 2000), this and other research (Chung and Poon 2000) found it to be too general to show significant differences in values important to $\mathrm{OW}$ membership. Results of this study support the hypothesis that general environmental attitudes may not predict specific behaviors (Kennedy et al. 2009). Other proxies, like specific seafood knowledge, were found to be better predictors of membership. Although causation was not established, personal experiences with an issue, i.e., observing that fish are much smaller than previous years, are expected to be associated with greater commitment to ERB (Clayton and Brook 2005).

The commitment by OW restaurants to a range of green activities creates marketing potential. Hu et al. (2010) recommend that restaurants inform their customers of their commitment to environmental issues because competitive advantage can be gained through promotion of themselves as leaders in the environmental field. This advantage could encourage nonmember restaurateurs to join the OW program.

Economic factors, including program fees and extra cost of sustainable seafood options, were not found to be a factor limiting program membership. Results of this study support research by Jaffry et al. (2004) that niche items can demand a price premium. Ocean Wise restaurateurs scored the importance of sustainability significantly higher, both in rank and value, than non-OW restaurateurs. Although rank and value scored low compared to other factors, seafood typically leaves low profit margins (Kim and Upneja 2014) which necessitates high concern for cost. This finding is supported by Poulston and Yiu (2011) who found that profit generation must be prioritized, and cannot always occur concurrently with environmental protection.

For an environmental message to achieve positive results, consumers must trust its credibility (McKenzie-Mohr 1994). This research shows that, overwhelmingly, restaurateurs are confident that $\mathrm{OW}$ is a reliable source of information on sustainable seafood. By targeting high-end restaurants (M. McDermid, personal communication, 2012), OW has effectively set trends that others will follow (Poulston and Yiu 2011). To grow the program further, OW should continue to take advantage of the innovative chefs involved in the program to help spread the message of sustainable fisheries (Rogers 2003).

The discovery of multiple nonmember restaurateurs using the OW logo was an unexpected result of this research. Although this suggests that restaurateurs see value in the logo, it also could undermine the credibility of the program. The OW $\operatorname{logo}$ is trademarked, and staff should take incidences of inappropriate use very seriously to ensure that program integrity does not begin to be questioned by consumers or member restaurateurs.

Although the impacts that consumer based marketing programs have on seafood stocks are not easily determined (Ward 2008), the importance of education to environmentally sustainable behavior is well established (e.g., Hungerford and Volk 1990, Kasim and Ismail 2012). Continued growth of the program and increased awareness across Canada are achievable goals for the OW program. Further collaboration with other sustainability organizations, restaurant organizations, and government will aid in achievement of the program goals.

Information related to the transparency, consistency, and clarity of the OW program, relative to other sustainable seafood programs, was not examined in this study. Ocean Wise staff are working on data tracking to be able to provide volume data and quantitative information on the number of unsustainable seafood items removed from member restaurants (M. McDermid, personal communication, 2012). Having this information available will allow future research to begin to quantify the effect of the OW program.

\section{CONCLUSION}

The goal of consumer-based marketing programs is to force market change through increased knowledge and public pressure. In this study we provide insight into the types of restaurants and restaurateurs drawn to the OW program.

The OW program has well established itself in a growing niche market. Sustainability programs, whether seafood based or otherwise, can educate the public and create change, without offsetting profitability. In Vancouver, OW is a fixture at most highend restaurants and many casual establishments. The growth of the program, both in restaurant numbers and volume of sustainable seafood is obvious in Vancouver, and is spreading across Canada. Results of this research can help OW to focus resources on recruiting restaurateurs who may be predisposed to sustainable seafood messages. Further, suggestions for highlighting overall green commitment by OW restaurants may promote market access to consumers with general concern for the environment.

The current crisis facing world fish populations is at such a point that consumer-based techniques alone are not the solution. These programs can, however, educate and empower consumers to vote with their wallets, forcing large-scale changes on the water. When combined with changes in management and other marine conservation efforts, programs such as OW can play an important role in achieving sustainable fisheries.

Responses to this article can be read online at: http://www.ecologyandsociety.org/issues/responses. $\mathrm{php} / 8491$

\section{Acknowledgments:}

Thank you to the Vancouver restaurateurs who took the time to participate in this research and provide valuable information for the Ocean Wise program, and other sustainable seafood initiatives.

\section{LITERATURE CITED}

Agnew, D. J., J. Pearce, G. Pramod, T. Peatman, R. Watson, J. R. Beddington, and T. J. Pitcher. 2009. Estimating the worldwide extent of illegal fishing. PLOS ONE 4(2):e4570. http://dx.doi. org/10.1371/journal.pone.0004570 
Bostock, J., B. McAndrew, R. Richards, K. Jauncey, T. Telfer, K. Lorenzen, D. Little, L. Ross, N. Handisyde, I. Gatward, and R. Corner. 2010. Aquaculture: global status and trends. Philosophical Transactions of the Royal Society Biological Sciences 365(1554):2897-2912. http://dx.doi.org/10.1098/rstb.2010.0170

Boström, M. 2006. Establishing credibility: practicing standardsetting ideals in a Swedish seafood-labelling case. Journal of Environmental Policy \& Planning 8(2):135-158. http://dx.doi. org/10.1080/15239080600772126

Bowen, F., and J. A. Aragon-Correa. 2014. Greenwashing in corporate environmentalism research and practice: the importance of what we say and do. Organization and Environment 27(2):107-112. http://dx.doi.org/10.1177/1086026614537078

Bruce, C., and A. Laroiya. 2007. The production of eco-labels. Environment and Resource Economics 36:275-293. http://dx.doi. org/10.1007/s10640-006-9028-9

Bush, S. R., P. Oosterveer, M. Baily, and A. P. J Mol. 2015. Sustainability governance of chains and networks: a review and future outlook. Journal of Cleaner Production 107(16):8-19. http://dx.doi.org/10.1016/j.jclepro.2014.10.019

Chung, S.-S., and C.-S. Poon. 2000. A comparison of waste reduction practices and the New Environmental Paradigm in four southern Chinese areas. Environmental Management 26 (2):195-206. http://dx.doi.org/10.1007/s002670010081

City of Vancouver. 2015. Greenest city action plan. City of Vancouver, British Columbia, Canada. [online] URL: $\underline{\text { http:// }}$ vancouver.ca/green-vancouver/greenest-city-action-plan.aspx

Clayton, S., and A. Brook. 2005. Can psychology help save the world? A model for conservation psychology. Analyses of Social Issues and Public Policy 5(1):87-102. http://dx.doi.org/10.1111/ j.1530-2415.2005.00057.x

Cordano, M., S. A. Welcomer, and R. F. Scherer. 2003. An analysis of the predictive validity of the New Environmental Paradigm Scale. Journal of Environmental Education 34(3):22-28. http://dx. doi.org/10.1080/00958960309603490

Dauvergne, P., and J. Lister. 2012. Big brand sustainability: governance prospects and environmental limits. Global Environmental Change 22:36-45. http://dx.doi.org/10.1016/j. gloenvcha.2011.10.007

De Young, R. 1993. Changing behaviour and making it stick: the conceptualization and management of conservation behaviour. Environment and Behaviour 25:485-505. http://dx.doi. org/10.1177/0013916593253003

Dunlap, R. E., K. D. Van Liere, A. G. Mertig, and R. E. Jones. 2000. New trends in measuring environmental attitudes: measuring endorsement of the New Environmental Paradigm: a revised NEP scale. Journal of Social Issues 56(3):425-442. http:// dx.doi.org/10.1111/0022-4537.00176

Environmental Justice Foundation. [date unknown]. Ending pirate fishing. Environmental Justice Foundation, London, UK. [online] URL: http://ejfoundation.org/campaigns/oceans/item/ ending-pirate-fishing

Foley, P. 2012. The political economy of Marine Stewardship Council certification: processors and access in Newfoundland and
Labrador's inshore shrimp industry. Journal of Agrarian Change 12(2-3):436-547. http://dx.doi.org/10.1111/j.1471-0366.2011.00344. $\underline{\mathrm{X}}$

Food and Agriculture Organization. 2011. World aquaculture 2010. FAO, Rome, Italy. [online] URL: http://www.fao.org/ docrep/014/ba0132e/ba0132e.pdf

Food and Agriculture Organization. 2014. The state of world fisheries and aquaculture. FAO, Rome, Italy. [online] URL: http:// www.fao.org/3/a-i3720e.pdf

Freeman, E. M. 2011. Restaurant industry sustainability: barriers and solutions to sustainable practice indicators. Thesis. Arizona State University, Phoenix, Arizona, USA.

Golden, R. E., and K. Warner. 2014. The global reach of seafood fraud: a current review of the literature. Oceana, Washington, D. C., USA. [online] URL: https://usa.oceana.org/sites/default/files/ seafood_fraud_map_white_paper_new_0.pdf

Gulbrandsen, L. H. 2009. The emergence and effectiveness of the Marine Stewardship Council. Marine Policy 33:654-660. http:// dx.doi.org/10.1016/j.marpol.2009.01.002

Gupta, N. J., and C. C. Benson. 2011. Sustainability and competitive advantage: an empirical study of value creation. Competitive Forum 9(1):121-136.

Handfield, R., R. Sroufe, and S. Walton. 2005. Integrating environmental management and supply chain strategies. Business Strategy and the Environment 14:1-19. http://dx.doi.org/10.1002/ bse. 422

Hanner, R., S. Becker, N. V. Ivanova, and D. Steinke. 2011. FISHBOL and seafood identification: geographically dispersed case studies reveal systemic market substitution across Canada. Mitochondrial DNA 22(1):106-122. http://dx.doi. org/10.3109/19401736.2011.588217

Hu, H., H. G. Parsa, and J. Self. 2010. The dynamics of green restaurant patronage. Cornell Hospitality Quarterly 51 (3):344-362. http://dx.doi.org/10.1177/1938965510370564

Hungerford, H. R. and T. I. Volk. 1990. Changing learner behaviour through environmental education. Journal of Environmental Education 21(3):8-21. http://dx.doi. org/10.1080/00958964.1990.10753743

Iles, A. 2007. Making the seafood industry more sustainable: creating production chain transparency and accountability. Journal of Cleaner Production 15:577-589. http://dx.doi. org/10.1016/j.jclepro.2006.06.001

Jacquet, J., J. Hocevar, S. Lai, P. Majluf, N. Pelletier, T. Pitcher, E. Sala, R. Sumaila, and D. Pauly. 2010. Conserving wild fish in a sea of market-based efforts. Oryx 44(1):45-56. http://dx.doi. org/10.1017/S0030605309990470

Jacquet, J., and D. Pauly. 2008b. Funding priorities: big barriers to small-scale fisheries. Conservation Biology 22(4):832-835. http://dx.doi.org/10.1111/j.1523-1739.2008.00978.x

Jacquet, J. L., and D. Pauly. 2008a. Trade secrets: renaming and mislabeling of seafood. Marine Policy 32:309-318. http://dx.doi. org/10.1016/j.marpol.2007.06.007 
Jaffry, S., H. Pickering, Y. Ghulam, D. Whitmarsh, and P. Wattage. 2004. Consumer choice for quality and sustainability labelled seafood products in the UK. Food Policy 29:215-228. http://dx. doi.org/10.1016/j.foodpol.2004.04.001

Johnson, D. B. 1998. Green businesses: perspectives from management and business ethics. Society \& Natural Resources 11 (3):259-266. http://dx.doi.org/10.1080/08941929809381078

Kasim, A., and A. Ismail. 2012. Environmentally friendly practices among restaurants: drivers and barriers to change. Journal of Sustainable Tourism 20(4):551-570. http://dx.doi. org/10.1080/09669582.2011.621540

Kemmerly, J. D. and V. Macfarlane. 2009. The elements of a consumer-based initiative in contributing to positive environmental change: Monterey Bay Aquarium's seafood watch program. Zoo Biology 28:398-411. http://dx.doi.org/10.1002/ Z0o.20193

Kennedy, E. H., T. M. Beckley, B. L. McFarlane, and S. Nadeau. 2009. Why we don't "walk the talk": understanding the environmental values/behaviour gap in Canada. Research in Human Ecology 16(2):151-160.

Kim, S. Y., and A. Upneja. 2014. Predicting restaurant financial distress using decision tree and AdaBoosted decision tree models. Economic Modelling 36:54-362. http://dx.doi.org/10.1016/j. econmod.2013.10.005

Konefal, J. 2013. Environmental movements, market-based approaches, and neoliberalization: a case study of the sustainable seafood movement. Organization \& Environment 26(3):336-352. http://dx.doi.org/10.1177/1086026612467982

Laroche, M., J. Bergeron, and G. Barbaro-Forleo. 2001. Targeting consumers who are willing to pay more for environmentally friendly products. Journal of Consumer Marketing 18(6):503-520. http://dx.doi.org/10.1108/eum0000000006155

Lee, C. S., J. T. Barnowe, and D. E. McNabb. 2005. Environmental perceptions, attitudes and priorities: cross-cultural implications for public policy. Cross Cultural Management 12(1):61-83. http:// dx.doi.org/10.1108/13527600510797962

McCright, A. M. 2010. The effects of gender on climate change knowledge and concern in the American public. Population and Environment 32:66-87. http://dx.doi.org/10.1007/s11111-010-0113-1

McKenzie-Mohr, D. 1994. Social marketing for sustainability: the case of residential energy conservation. Futures 26(2):224-233. http://dx.doi.org/10.1016/0016-3287(94)90111-2

McKenzie-Mohr, D. 2000. Fostering sustainable behaviour through community-based social marketing. American Psychologist 55(5):531-537. http://dx.doi.org/10.1037/0003-066X.55.5.531

Mendleson, N., and M. J. Polonsky. 1995. Using strategic alliances to develop credible green marketing. Journal of Consumer Marketing 12(2):4-18. http://dx.doi.org/10.1108/07363769510084867

Mobley, C., W. M. Vagias, and S. L. DeWard. 2010. Exploring additional determinants of environmentally responsible behaviour: the influence of environmental literature and environmental attitudes. Environment and Behaviour 42 (4):420-447. http://dx.doi.org/10.1177/0013916508325002
Moye, P. A. 2010. Private certification versus public certification in the international environmental arena: the Marine Stewardship Council and Marine Eco-Label Japan fisheries certification schemes as a case study. Vanderbilt Journal of Transitional Law 43:533-564.

Ocean Wise. [date unknown]. About Ocean Wise. Ocean Wise, Vancouver Aquarium, Vancouver, British Columbia, Canada. [online] URL: http://oceanwise.ca/about2

Olli, E., G. Grendstad, and D. Wollebaek. 2001. Correlates of environmental behaviors: bringing back social context. Environment and Behavior 33:181-208. http://dx.doi.org/ $\underline{10.1177 / 0013916501332002}$

Osbaldiston, R., and K. M. Shelton. 2003. Promoting internalized motivation for environmentally responsible behaviour: a prospective study of environmental goals. Journal of Environmental Psychology 23:349-357. http://dx.doi.org/10.1016/ $\underline{\mathrm{S} 0272-4944(03) 00035-5}$

Parkes, G., J. A. Young, S. F. Walmsley, R. Abel, J. Harman, P. Horvat, A. Lem, A. MacFarlane, M. Mens, and C. Nolan. 2010. Behind the signs - a global review of fish sustainability information schemes. Reviews in Fisheries Science 18(4):344-356. http://dx.doi.org/10.1080/10641262.2010.516374

Peattie, K. 2010. Green consumption: behaviour and norms. Annual Review of Environment and Resources 35:195-228. http:// dx.doi.org/10.1146/annurev-environ-032609-094328

Ponte, S. 2012. The Marine Stewardship Council (MSC) and the making of a market for 'sustainable fish.' Journal of Agrarian Change 12(23):300-315. http://dx.doi.org/10.1111/j.1471-0366.2011.00345. $\underline{\mathrm{x}}$

Poulston, J., and A. Y. K. Yiu. 2011. Profit or principles: Why do restaurants serve organic food? International Journal of Hospitality Management 30(1):184-191. http://dx.doi.org/10.1016/ j.ijhm.2010.04.004

Roberts, J. 2010. Voicing your ethical stance. Marketing Week, 2 March. [online] URL: https://www.marketingweek.com/-2010/03/02/ voicing-your-ethical-stance/

Roberts, J. S., J. E. Laughlin, and D. H. Wedell. 1997. Comparative validity of the Likert and Thurstone approaches to attitude measurement. Presentation, Annual Meeting of the American Educational Research Association. Institute of Education Sciences, Washington, D.C., USA. [online] URL: http://eric.ed. gov/?id=ED409328

Rogers, E. M. 2003. Diffusion of innovations. Fifth Edition. Free Press, Toronto, Ontario, Canada.

Roheim, C. A. 2003. Early indications of market impacts from the Marine Stewardship Council's ecolabeling of seafood. Marine Resource Economics 18(1):95-104. http://dx.doi.org/10.1086/ $\underline{\text { mre.18.1.42629385 }}$

Salomon, M., and K. Holm-Müller. 2013. Towards a sustainable fisheries policy in Europe. Fish and Fisheries 14(4):625-638. http:// dx.doi.org/10.1111/faf.12009

Schubert, F., J. Kandampully, D. Solnet, and A. Kralj. 2010. Exploring consumer perceptions of green restaurants in the US. 
Tourism and Hospitality Research 10(4):286-300. http://dx.doi. org/10.1057/thr.2010.17

Schultz, P. W. 2000. New environmental theories: empathizing with nature: the effects of perspective taking on concern for environmental issues. Journal of Social Issues 56(3):391-406. http://dx.doi.org/10.1111/0022-4537.00174

Seafood Choices Alliance. 2007. The UK marketplace for sustainable seafood. Seafood Choices Alliance, London, UK. [online] URL: http://www.seafoodchoices.org/resources/documents/ SCAUKMPReport.pdf

Seafood Watch. 2015. Our standards. Seafood Watch, Monterey, California, USA. [online] URL: http://www.seafoodwatch.org/ $\underline{\text { seafood-recommendations/our-standards }}$

Shelton, P. A. 2009. Eco-certification of sustainably managed fisheries - redundancy or synergy. Fisheries Research 100 (3):185-190. http://dx.doi.org/10.1016/j.fishres.2009.08.004

Sklandany, M., and P. Vandergeest. 2004. Catch of the day: seafood campaigns are reaching consumers but they risk oversimplification. Alternative Journal 30(2):24-26.

Smith, K. N., J. H. Shaw, T. Bettinger, B. Caniglia, and T. Carter. 2007. Conservation partnerships between zoos and aquariums, federal and state agencies, and nongovernmental organizations. Zoo Biology 26:471-486. http://dx.doi.org/10.1002/zoo.20142

Stubblefield-Loucks, E., M. L. Martens, and C. H. Cho. 2010. Engaging small and medium-sized businesses in sustainability. Sustainability Accounting Management and Policy Journal 1 (2):178-200. http://dx.doi.org/10.1108/20408021011089239

Verbeke, W., I. Vermeir, and K. Brunsø. 2007. Consumer evaluation of fish quality as basis for market segmentation. Food Quality and Preference 18(4):651-661. http://dx.doi.org/10.1016/ j.foodqual.2006.09.005

Ward, T. J. 2008. Barriers to biodiversity conservation in marine fishery certification. Fish and Fisheries 9:169-177. http://dx.doi. org/10.1111/j.1467-2979.2008.00277.x 
Appendix 1. Interview guide.

\section{Ocean Wise Restaurateur Survey}

Form A: Ocean Wise Restaurants

Interviewee Name:

Interviewee Job Title/Position:

Restaurant:

Date and Time of Interview:

Section 1: Restaurant background (from

menu)

\# of menu items

\# of menu items that are seafood

\# of menu items that are sustainable seafood

Dollar value sustainable items

Dollar value unsustainable items

Section 2: Sustainable seafood background knowledge

Please describe what "sustainable seafood" means to you. What are the key issues involved?

Section 3: Business Background

3.1 How long has your restaurant been in business?

3.2 How long have you (head chef) been with the restaurant?

3.3 How would you describe your cuisine?

3.4 How important is seafood to the image of your restaurant?

3.5 What percentage of these sales are sustainable seafood items?

Section 4: Seafood Purchasing

4.1 Who supplies your seafood?

4.2 Is the majority of your seafood wild or farmed?

4.3 What fishing methods are used for the seafood that you purchase?

4.4 What are the most important factors, from your perspective, when it comes to purchasing seafood (price, supply, quality, environmental quality etc)?

a. How important are each of these factors when purchasing seafood? $(1=$ not at all important...5= extremely important)

- Price

- Taste

- Quality

- Freshness

- Environmental Sustainability

b. Rank from 1-5 (with 1 being the most important and 5 the least) the priority of each of the following when purchasing seafood

- Price

- Taste

- Quality

- Freshness

- Environmental Sustainability

4.5 Would you pay more for

- Sustainable seafood? Yes/No?

- Local seafood? Yes/No?

- Higher quality seafood? Yes/No?

- How much more would you be willing to pay for these things (percentage)

4.6 How much seafood do you sell (kg/week)?

Section 5: Environmental Behaviour

5.1 Does your restaurant commit to any other green activities (recycling etc.)

5.2 Are you a member of the Green Restaurant Association or any other conservation group?

Section 6: Involvement with Ocean Wise 6.1 Initial Incentive and Services Received

a. Why did you decide to become involved with Ocean Wise?

b. How did you first hear about the program? 
c. How did you first becoming involved?

6.2 How long has your restaurant been involved with Ocean Wise? Don't know

a. Have you personally noticed changes in fish stocks over the years that you have been serving seafood?

b. Which of the following services offered by the Ocean Wise program have you received?

- Advertising

- Training

- Sourcing Seafood

- Marketing events

- Other (please describe)

- Which of these services do you feel is most valuable to your business?

6.3 Ways in Which Restaurant is Currently Using Ocean Wise

a. Do you provide information to customers in addition to the menu statement?

b. Are your staff members trained to understand and answer questions regarding the Ocean Wise program?

6.3 Perceived Benefits of Ocean Wise
a. How do customers respond to the program?

b. Has the program had a financial impact on your restaurant? (in terms of overall sales, reputation, attracting a particular customer base, etc.)? If so, what impact has it had?

c. What do you feel are the impacts of your involvement in the program on fisheries/fish stocks?

\subsection{Barriers to Providing Sustainable Seafood}
a. Do you have trouble finding the sustainable sources for the seafood

items you wish to sell? Please describe.

b. Are the sustainable options more expensive than non-sustainable options? Is this expense significant?

6.5 Overall Satisfaction/Perceptions of Impacts

a. How satisfied are you, overall, with the Ocean Wise program (1-not at all satisfied, 5=extremely satisfied)

b. How important is your participation in the program in terms of the image that you want to create for your business ( $1=$ not at all important, $5=$ extremely important)

c. By supporting programs like Ocean Wise, how significant a role do you think that restaurants can have in ensuring sustainable fisheries? ( $1=$ not a very significant role, $5=\mathrm{a}$ very significant role)

\subsection{Additional Services Needed}

a. What additional services could Ocean Wise provide that would benefit your business?

\section{Section 7: Reliability of the message}

7.1 Do you feel that Ocean Wise is a reliable source for information on sustainable seafood?

a. Would you feel more confident in a label from another NGO?

b. Would you feel more confident in a label created by a government organisation, such as the DFO? 
Appendix 2. Survey guide.

Knowledge and Attitude Survey

Part A: Sustainable Seafood Knowledge

1. How would you describe your overall knowledge of sustainable fishing/fish farming practices (1- not at all knowledgeable 2- not knowledgeable 3- neutral 4- somewhat knowledgeable

5- completely knowledgeable)

2. How would you describe your overall knowledge of sustainable seafood products (1- not at all knowledgeable 2not knowledgeable 3- neutral 4somewhat knowledgeable 5completely knowledgeable

3. Which of the following seafood products do you believe are typically fished or farmed in a sustainable manner? (Circle all that apply)
a. Wild caught Chilean sea bass
b. Farmed Arctic char
c. Wild caught Pacific cod
d. Wild caught Atlantic cod
e. Farmed Atlantic halibut
f. Wild caught Pacific halibut
g. Wild caught Coho salmon
h. Farmed Atlantic salmon
i. Wild caught Pacific spot prawn
j. Farmed tiger prawn

4. Which of the following methods of fishing do you believe are sustainable? (Circle all that apply)
a. Trolling (hook and line)
b. Benthic Long-lining
c. Mid-water long-lining
d. Benthic trawl
e. Mid-water trawl
f. Seining
g. Trap

5. In your opinion, what criteria apply to sustainable seafood? (Circle all that apply)

a. Must be wild caught

b. Cannot be a threatened species

c. Free of antibiotics

d. Has organic certification

e. Has no preservatives

f. Caught using fishing methods that reduce bycatch and minimize damage to the environment

6. In your opinion, are government regulations strict enough with regards to fisheries and aquaculture, circle one: too strict, okay, not strict enough, don't know

7. How much emphasis do you place on the following issues when you are making decisions to purchase specific seafood for your restaurant: $(1=$ no emphasis; $5=$ a great deal of emphasis)

a. Whether the seafood is in a category that has been overfished

b. Whether the fishing gear that was used causes damage to habitat

c. Whether the fishing technique results in bycatch

d. Impacts of aquaculture on the environment

e. Whether the seafood is caught locally

f. Whether the seafood is delivered fresh

g. The price of the seafood

h. The taste of the seafood 
Part B: Revised New Environmental Paradigm

Balance of Nature

In your opinion, how do you feel about the following statements (1- strongly disagree, 2disagree 3-somewhat disagree, 4- neutral 5somewhat agree 6-agree 7- strongly agree)

1. When humans interfere with nature, it often produces disastrous consequences

2. The balance of nature is very delicate and easily upset

3. The balance of nature is strong enough to cope with the impacts of modern industrial nations

\section{Eco-Crisis}

In your opinion, how do you feel about the following statements (1- strongly disagree, 2- disagree 3-somewhat disagree, 4- neutral 5- somewhat agree 6agree 7 - strongly agree)

4. Humans are severely abusing the environment

5. The so-called "ecological crisis" facing humankind has been greatly exaggerated

6. If things continue on their present course, we will soon experience a major ecological catastrophe

Antiexemptionalism

In your opinion, how do you feel about the following statements (1- strongly disagree, 2- disagree 3-somewhat disagree, 4- neutral 5- somewhat agree 6agree 7- strongly agree)

7. Human ingenuity will insure that we do not make the earth unliveable
8. Despite our abilities, humans are still subject to the laws of nature

9. Humans will eventually learn enough about how nature works to be able to control it

Limits to Growth

In your opinion, how do you feel about the following statements (1- strongly disagree, 2- disagree 3-somewhat disagree, 4- neutral 5- somewhat agree 6agree 7 - strongly agree)

10. The earth is like a spaceship with very limited room and resources

11. We are approaching the limit to the number of people the earth can support

12. The earth has plenty of natural resources if we just learn how to develop them

Antianthropocentrism (Human Domination)

In your opinion, how do you feel about the following statements (1- strongly disagree, 2- disagree 3-somewhat disagree, 4- neutral 5- somewhat agree 6agree 7 - strongly agree)

13. Plants and animals have as much right as humans to exist

14. Humans have the right to modify the natural environment to suit their needs

15. Humans were meant to rule over the rest of nature 